\title{
An Aggregate Import Demand Function for India: A Cointegration Analysis
}

Dilip Dutta and Nasiruddin Ahmed*

School of Economics and Political Science, University of Sydney

NSW 2006 Australia

All correspondence to:

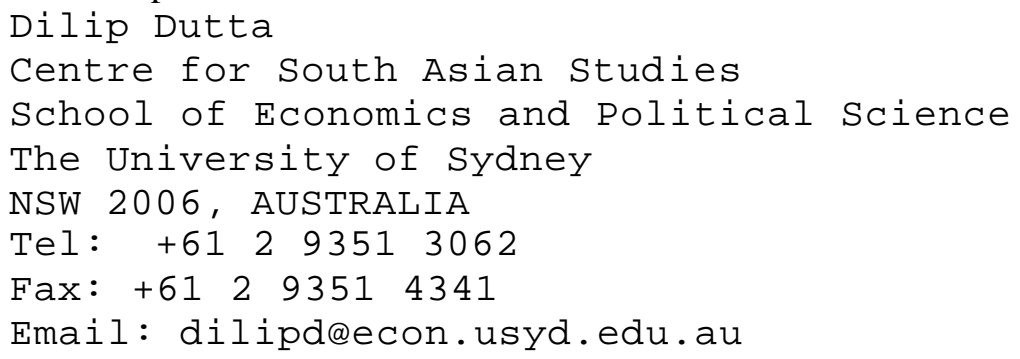

\begin{abstract}
This paper investigates the behaviour of Indian aggregate imports during the period 1971-1995. In our empirical analysis of the aggregate import demand function for India, cointegration and error correction modelling approaches have been used. In the aggregate import demand function for India, import volume is found to be cointegrated with relative import price and real GDP. Our econometric estimates of the import-demand function for India suggest that import-demand is largely explained by real GDP, and is generally less sensitive to import price changes. Import liberalisation is found to have had little impact on import demand.
\end{abstract}

\section{Section 1}

\section{Introduction}

In a recent paper, Sinha (1996) investigated the behaviour of Indian aggregate imports and argued that there was no empirical evidence in favour of the existence of any cointegrated relationship among the variables used in the aggregate import demand function during the period 1960-92. In this paper we reinvestigate the problem using data for the period 1971-95. Specifically, the objectives of the paper are two fold. In the first place, we intend to determine whether there exists a long-run relationship between India's aggregate import volume and its major determinants, on the basis of annual data for the period 1971-95. The hypothesis of the existence of a cointegrated relationship between aggregate import volume and its major determinants is tested using cointegration technique developed by Johansen $(1988,1991)$ and Johansen-Juselius (1990, 1992 and 1994). Secondly, this paper also investigates the effect of India's import liberalisation policy on its demand for imports. The remainder of this paper is organised as follows. Section 2 gives an overview of import liberalisation in India. The import demand function for India is modelled in section 3. In section 4, the empirical 
results are reported and discussed. Section 5 concludes the paper.

\section{Section 2}

\section{Import Liberalisation in India}

Prior to the nineties, the import regime of India was dominated by both quantitative restrictions on imports and a highly protectionist import tariff structure. The tariff structure was characterised by a very high or prohibitive tariff on final goods and a lower tariff on intermediate and primary products. This anomalous import regime, among other factors, has been a major stumbling block for the sustained growth of an efficient industrial structure in India. During the periods 1963-73 and 1973-85 the World Bank classified 41 countries, including India, as "strongly inward-oriented" countries meaning that the overall incentive structure strongly favoured production for the domestic market ${ }^{1}$.

The Indian economy has been undergoing substantial changes since 1991. Reform efforts have been continual and strong since 1991, with significant changes occuring in 1993 (Dean, Desai and Riedel, 1994). Almost all areas of the economy have been opened to both domestic and foreign private investment, import licensing restrictions on intermediates and capital goods have been mostly eliminated, tariffs have been significantly reduced, and full convertibility of foreign exchange earnings has been established for current account transactions (Dutta, 1998, p. 11).

More specifically, the following import policy reforms have been introduced in India (Rana, 1997):

(i) Except for a small list of negative items, import licensing has virtually been abolished;

(ii) Quantitative restrictions on imports have been replaced by tariffs; and

(iii) Tariffs have been reduced in stages: the maximum tariff rate was reduced from 400 per cent in 1990-91 to 50 per cent in 1995, and the average duty has been reduced from about 50 per cent to 27 per cent during the same period.

To appreciate the prospects and problems arising out of import liberalisation in India, it may be useful to look into some of the historical trends in terms of the import orientation ratio, import penetration ratio, nominal rates of protection (NRP) and effective rates of protection (ERP) $)^{2}$. The data relates to five years before liberalisation (1986-90) and five years after (1991-95).

The import orientation ratio, measured as the average ratio of aggregate imports to GDP, is shown in Table 1. We find a higher import orientation ratio during the 1991-95 period $(8.74 \%)$ than that in the $1986-91$ period $(6.98 \%)$.

Table 1: Import Orientation Ratio in India, 1986-95

\begin{tabular}{|c|c|c|c|}
\hline Year & $\begin{array}{c}\text { Imports } \\
\text { (billions of n. c.) }\end{array}$ & $\begin{array}{c}\text { GDP } \\
\text { (billions of n. c.) }\end{array}$ & $\begin{array}{c}\text { Imports as \% of } \\
\text { GDP }\end{array}$ \\
\hline 1986 & 194.50 & 2929.50 & 6.64 \\
1987 & 216.13 & 3332.00 & 6.49 \\
1988 & 266.06 & 3957.80 & 6.72 \\
1989 & 334.01 & 4568.20 & 7.31 \\
1990 & 413.57 & 5355.30 & 7.72 \\
\hline
\end{tabular}




\begin{tabular}{|cccc|}
\hline 1991 & 459.38 & 6168.00 & 7.45 \\
1992 & 611.13 & 7059.20 & 8.66 \\
1993 & 694.46 & 8097.70 & 8.58 \\
1994 & 842.17 & 9536.80 & 8.83 \\
1995 & 1121.47 & 10985.80 & 10.21 \\
\hline & & 6.98 \\
$1986-90$ & & Periodic Averages & 8.74 \\
$1991-95$ & & & \\
\hline
\end{tabular}

Source: Based on IMF's International Financial Statistics (various issues).

Another outcome-based measure of import liberalisation is the import penetration ratio: the average ratio of aggregate imports to aggregate consumption. This is probably a more reliable indicator of restrictive trade policy than the import orientation ratio since in most developing countries, it is imports of consumption goods that are the most stringently restricted (Andriamananjara and Nash, 1997). Table 2 shows a higher import penetration ratio during 1991-95 than that in the period 1986-90.

Table 2: Import Penetration Ratio in India, 1986-95

\begin{tabular}{|c|c|c|c|}
\hline Year & $\begin{array}{c}\text { Imports } \\
\text { (billions of } n . \text { c.) }\end{array}$ & $\begin{array}{l}\text { Aggregate consumption } \\
\quad \text { (billions of n. c.) }\end{array}$ & $\begin{array}{c}\text { Imports as \% of } \\
\text { aggregate } \\
\text { consumption }\end{array}$ \\
\hline 1986 & 194.50 & 2332.30 & 8.34 \\
\hline 1987 & 216.13 & 2633.90 & 8.21 \\
\hline 1988 & 266.06 & 3047.50 & 8.73 \\
\hline 1989 & 334.01 & 3424.40 & 9.75 \\
\hline 1990 & 413.57 & 3921.50 & 10.55 \\
\hline 1991 & 459.38 & 4513.50 & 10.18 \\
\hline 1992 & 611.13 & 5087.80 & 12.01 \\
\hline 1993 & 694.46 & 5790.80 & 11.99 \\
\hline 1994 & 842.17 & 6701.60 & 12.57 \\
\hline 1995 & 1121.47 & 7617.10 & 14.72 \\
\hline \multicolumn{4}{|c|}{ Periodic Averages } \\
\hline $1986-90$ & & & 9.12 \\
\hline $1991-95$ & & & 12.29 \\
\hline
\end{tabular}

Source: Based on IMF's International Financial Statistics (various issues).

In order to compare the extent of protection of Indian industries through import tariffs, the nominal rate of protection (NRP) and the effective rate of protection (ERP) have been used.

Table 3: Nominal and Effective Rate of Protection in India, 1989-96

\begin{tabular}{|l|c|c|c|c|c|c|}
\hline \multicolumn{1}{|c}{ Items } & \multicolumn{2}{c|}{ Nominal Rate of Protection } & \multicolumn{3}{c|}{ Effective Rate of Protection } \\
& $\mathbf{1 9 8 9 - 9 0}$ & $\mathbf{1 9 9 3 - 9 4}$ & $\mathbf{1 9 9 5 - 9 6}$ & $\mathbf{1 9 8 9 - 9 0}$ & $\mathbf{1 9 9 3 - 9 4}$ & $\mathbf{1 9 9 5 - 9 6}$ \\
\hline A. Based on Tariff Rates & & & & & \\
Average (Import weighted) & 93.3 & 62.9 & 31.0 & 87.5 & 60.7 & 30.4 \\
Average (Simple) & 104.8 & 66.7 & 35.2 & 102.0 & 65.4 & 34.6 \\
Standard deviation & 36.2 & 26.5 & 14.5 & 48.2 & 33.4 & 18.5 \\
Coefficient of variation & 35 & 40 & 41 & 47 & 51 & 53 \\
B. Based on Collection Rates & & & & & & \\
Average (Import weighted) & 50.0 & 39.0 & $31.5^{*}$ & 48.8 & 39.3 & $32.1^{*}$ \\
& $(55.0)$ & $(37.0)$ & $(27.0)$ & & & \\
\hline
\end{tabular}




\begin{tabular}{|lcccccc|}
\hline Average (Simple) & 73.0 & 52.6 & $40.1^{*}$ & 76.6 & 55.0 & $42.0^{*}$ \\
Standard deviation & 40.0 & 33.0 & $27.8^{*}$ & 54.1 & 56.3 & $48.6^{*}$ \\
Coefficient of variation & 55.0 & 63.0 & $69.0^{*}$ & 71.0 & 102.0 & 116.0 \\
\hline
\end{tabular}

Note: * stands for the year 1994-95.

Source: Mehta (1997), p.781.

Table 3 shows that the average estimated ERP declined from 49 per cent in 1989-90 to 32 per cent in 1994-95, whereas the average NRP came down from 55 per cent in 1989-90 to 27 per cent in 1995-96. It is evident from the table that although the average NRP and ERP declined over the period 1989-96, their dispersion, as measured by coefficient of variation, shows an upward trend. The increased tariff dispersion may be because of (i) the prevalence of multiple tariff rates, and (ii) the continued provision of tariff concessions for end-users.

\section{Section 3}

\section{Modelling an Aggregate Import-Demand Function for India}

In modelling an aggregate import demand function for India, we follow the imperfect substitutes model, in which the key assumption is that neither imports nor exports are perfect substitutes for domestic goods of the countries under consideration (Goldstein and Khan, 1985). Since India imports only a relatively small fraction of total world imports, it may be quite realistic to assume that the world supply of imports to India is perfectly elastic. This assumption seems to be realistic in the case of India because the rest of the world may be able to increase its supply of exports to this country even without an increase in prices. This assumption of infinite import supply elasticity reduces our model to a single equation model of an import demand function.

Econometric investigations of import demand postulate that the demand for imports is a function of relative prices and real income (Houthakker and Magee, 1969; Le amer and Stern, 1970; Murray and Ginman, 1976; Goldstein and Khan, 1985; and Carone, 1996). Studies by Khan and Ross (1977) and Salas (1982) suggest that in modelling an aggregate import demand function, the log-linear specification is preferable to the linear formulation. Accordingly, the long-run import demand function for India is specified as follows:

LRIMPORT $_{t}=\alpha_{0}+\alpha_{1}$ LRIMPRICE $_{t}+\alpha_{2}$ LRGDP $_{t}+\alpha_{3} D_{t}+u_{t}$

where RIMPORT = real quantity of merchandise imports;

RIMPRICE = relative price of imports;

RGDP = gross domestic product at 1990 prices;

$\mathrm{D}=$ a dummy variable with values 0 for 1971-91 and 1 for 1992-95

to capture the effect of import liberalisation on import volume;

$\mathrm{u}=$ random disturbance term with its usual classical properties; and

$\mathrm{L}=$ natural logarithm 
It is expected that $\alpha_{1}<0$; and $\left(\alpha_{2}, \alpha_{3}\right)>0$.

The theory of demand suggests that quantity rather than value is the appropriate dependent variable. So we deflate the value series of imports c.i.f. by a measure of prices to obtain the proper dependent variable (see APPENDIX 1).

In the model, import price and real income (RGDP) variables are crucial, because the effectiveness of an import trade policy is highly dependent upon the size of their elasticities. The quantity of imports demanded depends upon the price of imports in domestic currency as well as the price of domestically produced substitutes. Since data on the price of domestically produced substitutes are simply not available, researchers use a more general price index, $i e$, the wholesale price index, the consumer price index, the GDP deflator etc. And thus, the range of goods covered in the domestic price index could differ substantially from those covered in the import unit value index.

A dummy variable has been included in the model to capture the effect of the import liberalisation policy on import demand. Import liberalisation, through easing access to imports, is likely to result in a larger aggregate import demand by the economy.

If the time series variables of LRIMPORT, LRIMPRICE $_{t}$, and LRGDP $_{t}$ have unit roots, then we need to take the first difference of the variables (as in equation 2) in order to obtain a stationary series:

$$
\Delta \text { LRIMPORT }_{\mathrm{t}}=\alpha_{0}+\alpha_{1} \Delta \text { LRIMPRICE }_{\mathrm{t}}+\alpha_{2} \Delta \mathrm{LRGDP}_{\mathrm{t}}+\alpha_{3} \mathrm{D}_{\mathrm{t}}+\mathrm{u}_{\mathrm{t}}
$$

Equatio n (2) ignores any reference to the long-run aspects of decision-making. That is, this procedure of differencing results in a loss of valuable "long-run information" in the data (Maddala, 1992). The theory of cointegration addresses this issue by introducing an error-correction (EC) term. The $\mathrm{EC}$ term lagged one period (ie., $\mathrm{EC}_{\mathrm{t}-1}$ ) integrates short-run dynamics in the long-run import demand function. This leads us to the specification of a general error correction model (ECM):

$$
\begin{aligned}
& \Delta \text { LRIMPORT }_{\mathrm{t}}=\beta_{0}+\sum_{i=1}^{n} \beta_{1 \mathrm{i}} \Delta \text { LRIMPORT }_{\mathrm{t}-\mathrm{i}}+\sum_{i=0}^{n} \beta_{2 \mathrm{i}} \Delta \text { LRIMPRICE }_{\mathrm{t}-\mathrm{i}}+ \\
& \sum_{i=0}^{n} \beta_{3 \mathrm{i}} \Delta \mathrm{LRGDP}_{\mathrm{t}-\mathrm{i}}+\beta_{4} \mathrm{EC}_{\mathrm{t}-1}+\beta_{5} \mathrm{D}_{\mathrm{t}}+\varepsilon_{\mathrm{t}}
\end{aligned}
$$

where $\mathrm{EC}_{\mathrm{t}-1}=$ error-correction term lagged one period.

The modelling strategy adopted in this study involves three steps:

(i) determining the order of integration of the variables by employing Dickey-Fuller (DF), Augmented Dickey-Fuller (ADF) and Phillips-Perron (1988) unit-root tests; (ii) if the variables are integrated of the same order, we apply the Johansen -Juselius $(1990,1992,1994)$ maximum likelihood method of cointegration ${ }^{3}$ to obtain the number of cointegrating vector(s); and 
(iii) if the variables are cointegrated, we can specify an error correction model and estimate it using standard methods and diagnostic tests.

\section{Section 4}

\section{Empirical Analysis}

\subsection{Summary Statistics}

Data on RIMPORT, RIMPRICE and RGDP for the 1971-1995 period are shown in

Table 4 as are their means, standard deviations (SD), coefficients of variation (CV), and annual compound growth rate.

Table 4: Summary Statistics of Variables Used

\begin{tabular}{|l|l|l|l|l|l|}
\hline Variable & Description & Mean & SD & CV & $\begin{array}{l}\text { Annual } \\
\text { compound growth } \\
\text { rate (\%) }\end{array}$ \\
\hline RIMPORT & $\begin{array}{l}\text { Volume of } \\
\text { imports }\end{array}$ & 3.47 & 2.06 & 0.59 & 6.9 \\
RIMPRICE & $\begin{array}{l}\text { Relative } \\
\text { import price }\end{array}$ & 36.26 & 9.42 & 0.26 & 1.2 \\
RGDP & $\begin{array}{l}\text { Real Gross } \\
\text { Domestic } \\
\text { Product }\end{array}$ & 3977.3 & 1556.1 & 0.39 & 4.9 \\
\hline
\end{tabular}

Note: Annual compound growth rates are trend values significant at 5 per cent level.

Source: Authors' calculation based on IMF's International Financial Statistics (various issues).

\subsection{Unit-Root Tests}

In this section we analyse the time-series properties of the data during the period 19711995. We have conducted the Dickey-Fuller (DF), Augmented Dickey-Fuller (ADF), and Phillips-Perron (PP) unit root tests. These unit-root tests are performed on both levels and first differences of all the three variables.

The DF-ADF tests (Table 5) and the PP test (Table 6) confirm stationarity for all the three variables (LRIMPORT, LRIMPRICE and LGDP). Interestingly, however, first differencing of all the variables shows stationarity under the tests.

Table 5: DF-ADF unit root tests for stationarity

\begin{tabular}{|c|c|c|c|c|c|c|}
\hline & & \multicolumn{2}{|c|}{ DF } & \multicolumn{2}{|c|}{ ADF (1) } & \multirow[b]{2}{*}{ Conclusion } \\
\hline Variables & $\begin{array}{l}\text { Level/ } \\
\text { First Diff. }\end{array}$ & $\begin{array}{l}\text { Without } \\
\text { Trend }\end{array}$ & $\begin{array}{l}\text { With } \\
\text { Trend }\end{array}$ & $\begin{array}{l}\text { Without } \\
\text { Trend }\end{array}$ & $\begin{array}{l}\text { With } \\
\text { Trend }\end{array}$ & \\
\hline \multirow[t]{2}{*}{ LRIMPORT } & Level & -0.03 & -2.49 & -0.11 & -2.86 & $\mathrm{I}(1)$ \\
\hline & First Diff. & -4.95 & -4.86 & -4.62 & 4.58 & $\mathrm{I}(0)$ \\
\hline \multirow[t]{2}{*}{ LRIMPRICE } & Level & -2.28 & -2.07 & -2.25 & -2.01 & $\mathrm{I}(1)$ \\
\hline & First Diff. & -5.26 & -5.19 & -4.95 & -5.06 & $\mathrm{I}(0)$ \\
\hline \multirow[t]{2}{*}{ LRGDP } & Level & 1.50 & -2.85 & 1.90 & -2.46 & $\mathrm{I}(1)$ \\
\hline & First Diff. & -5.91 & -6.38 & -3.63 & 4.19 & $\mathrm{I}(0)$ \\
\hline
\end{tabular}

Notes : (i) Unit root tests were performed using Microfit 4.0.

(ii) $95 \%$ critical values for ADF statistic (without trend) $=-2.90$

(iii) $95 \%$ critical values for ADF statistic (with trend) $=-3.46$

Table 6: Phillips -Perron (PP) unit root test for stationarity 


\begin{tabular}{|c|c|c|c|c|}
\hline Variables & $\begin{array}{l}\text { Level/ } \\
\text { First Diff. }\end{array}$ & $\begin{array}{l}\text { Constant, } \\
\text { No Trend } \\
\end{array}$ & $\begin{array}{l}\text { Constant, } \\
\text { Trend }\end{array}$ & Conclusion \\
\hline \multirow[t]{2}{*}{ LRIMPORT } & Level & -0.24 & -2.16 & $\mathrm{I}(1)$ \\
\hline & First Diff. & -5.00 & -5.01 & $\mathrm{I}(0)$ \\
\hline \multirow[t]{2}{*}{ LRIMPRICE } & Level & -2.43 & -2.18 & $\mathrm{I}(1)$ \\
\hline & First Diff. & -5.29 & -5.36 & $\mathrm{I}(0)$ \\
\hline \multirow[t]{2}{*}{ LRGDP } & Level & -2.03 & -2.41 & $\mathrm{I}(1)$ \\
\hline & First Diff. & -5.45 & -6.38 & $\mathrm{I}(0)$ \\
\hline
\end{tabular}

Notes: (i) PP test was performed using SHAZAM 8.0.

(ii) $95 \%$ critical values for ADF statistic (without trend) $=-2.90$

(iii) $95 \%$ critical values for ADF statistic (with trend) $=-3.46$

\subsection{Cointegration Tests}

Before undertaking cointegration tests, let us first specify the relevant order of lags $(p)$ of the Vector Autoregression (VAR) model. Given the annual nature of the data, $p=1$ seems to be a reasonable choice (Pesaran and Pesaran, 1997).

The results obtained from the above unit-root tests show that all the three variables are integrated of order one. On the basis of the above unit-root tests, we apply the Johansen (1988 and 1991) and Johansen and Juselius (JJ) (1990, 1992, 1994) cointegration tests. Table 7 presents the results obtained from the JJ method.

Table 7: Johansen-Juselius Maximum Likelihood Cointegration Tests

\begin{tabular}{|c|ccc|}
\hline Null & Alternative & Statistic & 95 \% Critical Value \\
\hline & & \multicolumn{2}{c|}{ Maximal Eigenvalue Test } \\
$\mathrm{r}=0$ & $\mathrm{r}=1$ & 36.34 & 22.04 \\
$\mathrm{r} \leq 1$ & $\mathrm{r}=2$ & 11.01 & 15.87 \\
$\mathrm{r} \leq 2$ & $\mathrm{r}=3$ & 5.63 & 9.16 \\
& & Trace Test & 34.87 \\
$\mathrm{r}=0$ & $\mathrm{r} \geq 1$ & 52.98 & 20.18 \\
$\mathrm{r} \leq 1$ & $\mathrm{r} \geq 2$ & 16.64 & 9.16 \\
$\mathrm{r} \leq 2$ & $\mathrm{r} \geq 3$ & 5.63 & \\
\hline
\end{tabular}

Notes: (i) The test was performed using Microfit 4.0.

(ii) $r$ stands for the number of cointegrating vectors.

In Table 7 the results of both maximal eigenvalue and trace tests are reported. Starting with the null hypothesis of no cointegration $(r=0)$ among the three variables of LRIMPORT, LRIMPRICE and LRGDP, both the maximal eigenvalue and the trace statistic suggest $r=1$. Therefore, we conclude that there is only one cointegrating relation among the variables. Estimates of long-run cointegrating vectors are given in Table 8.

Table 8: Estimates of Long -Run Cointegrating Vectors (Linearised)

\begin{tabular}{|lll|} 
LRIMPORT & LRIMPRICE & LRGDP \\
1.00 & -0.37 & -0.03 \\
& $(2.39)$ & $(3.92)$ \\
\hline
\end{tabular}

Notes : 1 . The long-run equilibrium relation is: LRIMPORT $=-0.37$ LRIMPRICE -0.03 LRGDP

2. Figures in parentheses indicate standard errors.

\subsection{Estimation of an Error-Correction Model}


Once a cointegrating relationship is established, then an Error-Correction Model (ECM) can be estimated to determine the dynamic behaviour of import demand.

Following Hendry's (1995) generat to-specific modelling approach, we first include 4 lags of the explanatory variables, and then gradually eliminate the insignificant variables. After experimenting with the general form of the ECM (equation 3), the following model is found to fit the data best (Table 9):

Table 9: Estimated Error-Correction Model

\begin{tabular}{|l|l|l|l|}
\hline \multicolumn{4}{|c|}{ Dependent Variable: $\Delta$ LRIMPORT } \\
\hline Regressors & $\begin{array}{l}\text { Parameter } \\
\text { Estimates }\end{array}$ & T-Ratio & P-Values \\
\hline Intercept & 0.25 & 1.52 & 0.15 \\
$\Delta$ LRIMPRICE & -0.47 & -3.78 & 0.00 \\
LLRGDP(-2) & 1.48 & 1.97 & 0.05 \\
D & 0.14 & 1.51 & 0.15 \\
EC $(-1)$ & -0.12 & -1.98 & 0.05 \\
\hline Adj $R^{2}=0.59$ & & & \\
D. W. $=2.53$ & & & \\
Serial Correlation $=2.45(0.12)$ & & & \\
RESET $=0.65(0.42)$ & & & \\
Normality $=1.85(0.40)$ & & \\
HET $=0.02(0.88)$ & & & \\
\hline
\end{tabular}

In the above estimated model real import price, real GDP (lagged two years) and the dummy variable capturing the effect of import liberalisation on import volume have emerged as significant determinants of the import demand function for India.

The aggregate import volume is found to be price-inelastic, the coefficient estimate being -0.47 . The value of income elasticity of demand for imports lagged two years is greater than unity (1.48 in the model), implying that the demand for imports increases more than proportionately to the increase in real GDP. The income and price elasticity estimates are in line with the Goldstein-Khan ranges of $[-0.50,-1.0]$ for typical price elasticity and [1.0, 2.0] for typical income elasticity (Goldstein and Khan, 1985). The coefficient estimate of the dummy variable is low (0.14) and is statistically significant above 10 per cent level.

The estimated coefficient of the error correction term (-0.12) is statistically significant at the 5 per cent level and with the appropriate (negative) sign. This suggests the validity of a long-run equilibrium relationship among the variables in equation (1). The estimated coefficient value of -0.12 suggests that the system corrects its previous period's disequilibrium by 12 per cent a year. Diagnostic test statistics show no evidence of misspecification of functional form, no serial correlation, nor any problem of heteroscedasticity.

\section{Section 5}

\section{Summary and Conclusions}

In this paper we have examined the effect of import liberalisation on India's import demand both at the aggregate level. In our empirical analysis of the aggregate 
merchandise import demand function for India, cointegration and error correction modelling approaches have been used. In the aggregate import demand function, aggregate import volume is found to be cointegrated with relative import price and real GDP. In the estimated ECM, real import prices, real GDP (lagged two years) and a dummy variable, introduced to capture the effect of import liberalisation policies on import demand, have all emerged as important determinants of the import demand function for India. The estimated coefficient of the error correction term $(-0.12)$ indicates a slow speed of adjustment to equilibrium.

Our econometric estimates of the aggregate import-demand functions for India suggest that import-demand is largely explained by real GDP, which relates to the general level of economic activity in the country. The demand for imports appears to be less sensitive to import price changes. This implies that a lowering of import prices through removal of tariff and non-tariff barriers will not lead to a proportionate rise in the flow of imports. This also reflects the noncompetitive nature of India's imports. The result that the quantity of imports is influenced largely by changes in real GDP than import prices is significant, since it reveals the ineffectiveness of exchange rate policy in influencing import demand. Moreover, the low coefficient estimate of the dummy variable shows little effect of import liberalisation policy on aggregate import volume.

\section{References}

Andriamananjara, S. and J. Nash, (1997), "Have Trade Policy Reforms Led to Greater Openness in Developing Countries?", Policy Research Working Paper 1730, Washington, D.C.: The World Bank.

Carone, G. (1996), "Modeling the U. S. Demand for Imports Through Cointegration and Error Correction," Journal of Policy Modeling, 18(1):1-48.

Dean, J. M., S. Desai and J. Riedel (1994), Trade Policy Reform in Developing Countries since 1985: A Review of the Evidence, World Bank Discussion Papers 267.

Dickey, D. A. and W. A. Fuller (1981), "Likelihood Ratio Statistics for Autoregressive Time Series with a Unit Root," Econometrica, 49(4): 1057-1072.

Dutta, D. (1998), "Fifty years of economic development in India: rhetoric and reality," in P. K. Basu, N. D. Karunaratne and C. A. Tisdell (eds.), Fifty Years of Indian Development: India in Retrospect, Future Directions and Investment Outlook, Economics Conference Monograph No 5, The University of Queensland, Australia. and N. Ahmed (1997), "An Aggregate Import Demand Function for

Bangladesh: A Cointegration Approach,” Applied Economics, 31(1999):465-472.

Emran, M. S. and F. J. Shilpi (1996), "Foreign Exchange Rationing and the Aggregate Import Demand Function," Economics Letters, 51(3): 315-22. 
Engle, R. F. and C. W. J. Granger (1987), “Cointegration and Error Correction: Representation, Estimation and Testing," Econometrica, 55:251-76.

Goldstein, M. and M. S. Khan (1985), "Income and Price Effects in Foreign Trade," in R. W. Jones and P. B. Kenen (eds.) Handbook of International Economics (Vol. II), New York: Elsevier Science Publications, 1041-1105.

Hendry, D. F. (1995), Dynamic Econometrics, Oxford: Oxford University Press.

International Monetary Fund, International Financial Statistics (various issues).

Houthakker, H. S. and S. P. Magee (1969), "Income and Price Elasticities in World Trade," Review of Economics and Statistics, 41:111-25.

Johansen, S. (1988), "Statistical Analysis of Cointegrating Vectors," Journal of Economic Dynamics and Control, 12: 231-54. (1991), "Estimation and Hypothesis Testing of Cointegration Vectors in Gaussian Vector Autoregressive Models," Econometrica, 59: 1551-80. and K. Juselius (1990), "Maximum Likelihood Estimation and Inference on Cointegration with Applications to the Demand for Money," Oxford Bulletin of Economics and Statistics, 52: 169-210.

and K. Juselius (1992), "Testing Structural Hypothesis in a Multivariate Cointegration Analysis of the PPP and the UIP for UK," Journal of Econometrics, 53: $211-44$

and K. Juselius (1994), "Identification of the Long-Run and the ShortRun Structure: An Application to the ISLM Model," Journal of Econometrics, 63: 736.

Joshi, V. and I. M. D. Little (1994), India: Macroeconomics and Political Economy 1964-1991, Delhi: Oxford University Press.

Khan, M. S. and K. Z. Ross (1977), "The Functional Form of the Aggregate Import Equation," Journal of International Economics, 7:149-60.

Leamer, E. E. and R. M. Stern (1970), Quantitative International Economics, Boston, MA: Allyn and Bacon.

Maddala, G. S. (1992), Introduction to Econometrics (Second Edition), Englewood Cliffs, NJ: Prentice Hall, Inc.

Mehta, R. (1997), “Trade Policy Reforms, 1991-92 to 1995-96: Their Impact on External Trade," Economic and Political Weekly, 32(15):779-784.

Murray, T. and P. J. Ginman (1976), “An Examination of the Traditional Aggregate 
Import Demand Model," Review of Economics and Statistics, 58:75-80.

Pesaran, M. H. and B. Pesaran (1997), Working with Microfit 4.0: Interactive Econometric Analysis, Oxford: Oxford University Press.

Phillips, P. C. B. and P. P. Perron (1988), "Testing for a Unit Root in Time Series Regression," Biometrika, 75(2): 335-46.

Rana, P. B. (1997), "Reforms in Bangladesh: A Comparative Assessment in Relation to Other South Asian Countries," in M. G. Quibria (ed.) The Bangladesh Economy in Transition, Delhi: Oxford University Press.

Salas, J. (1982), "Estimation of the Structure and Elasticities of Mexican Imports in the Period 1961-1979," Journal of Development Economics, 10:297-311.

Senhadji, A. (1998), "Time-Series Estimation of Structural Import Demand Equations: A Cross-Country Analysis," IMF Staff Papers, 45(2): 236-268.

Sinha, D. (1996), “An Aggregate Import Demand Function for India,” Rivista Internazionale di Scienze Economiche e Commerciali, 43(1996): 163-173.

Thomas, V., J. Nash, and Associates (1991), Best Practices in Trade Policy Reform, Oxford: Oxford University Press for the World Bank.

World Bank (1987), World Development Report 1987.

\section{APPENDIX 1 \\ Variable Definitions and Data Sources of an Aggregate Import Demand Function for India}

In the empirical analysis of an aggregate import demand function for India we use annual data for the period 1971-1995. All the variables are expressed in real terms. Natural logarithms are taken on all variables.

RIMPORT: Nominal value of aggregate merchandise imports c.i.f. is deflated by the unit value index of imports $(1990=100)$ to obtain real quantity of imports.

Source: IMF, International Financial Statistics (various issues).

RIMPRICE: Relative price of imports $(1990=100)$. This is obtained by the unit value index of imports $(1990=100)$, adjusted for import tariff rate, deflated by Wholesale Price Index.

Source: IMF, International Financial Statistics (various issues).

RGDP: Gross Domestic Product at 1990 prices. .

Source: IMF, International Financial Statistics (various issues). 
$\mathbf{D}=$ An intercept dummy variable with values 0 for 1971-1991 and 1 for 1992-1995 is taken to capture the effect of import liberalisation on the volume of aggregate imports. 